\title{
Neubauer et al. versus Germany: Planetary Climate Litigation for the Anthropocene?
}

\author{
Louis J. Kotzé ${ }^{1}$ \\ ${ }^{1}$ Research Professor of Law, North-West University, Potchefstroom, South Africa \\ Corresponding author: Louis.Kotze@nwu.ac.za
}

(Received 21 November 2021; accepted 22 November 2021)

\begin{abstract}
The recent decision by the German Constitutional Court in Neubauer et al. versus Germany has been attracting considerable attention around the globe. The Court ordered the German legislature to correct and to significantly tighten up existing climate law provisions, to increase the ambition of these provisions, and to strengthen future mitigation pathways. Several commentators have hailed it as an example of what is possible when the judiciary steps in to fill gaps in global climate governance as a result of governments failing to act or acting inadequately. In this article, I explore the extent to which the Court in Karlsruhe has innovatively managed to embrace a holistic planetary view of climate science, climate change impacts, planetary justice, planetary stewardship, earth system vulnerability, and global climate law, within the context of a human-dominated geological epoch, to guide its reasoning and findings. My proposal is that courts will have to increasingly follow a planetary perspective that is grounded in the Anthropocene context when adjudicating matters related to global disruptors such as climate change. This decision offers a first, and important, example of a promising new paradigm that I term planetary climate litigation.
\end{abstract}

Keywords: Anthropocene; climate change; COP26; earth system governance; earth system law; Neubauer et al. versus Germany; planetary climate litigation

\section{A. Introduction}

The recent decision of the German Constitutional Court in Neubauer et al. versus Germany (hereafter Neubauer), ${ }^{1}$ is one in a wave of "ground-breaking" ${ }^{2}$ climate change cases sweeping

Louis J. Kotzé Research Professor, North-West University, South Africa; Senior Professorial Fellow in Earth System Law, University of Lincoln, United Kingdom. My sincere thanks to Duncan French, University of Lincoln; Henrike Knappe, Potsdam Institute for Advanced Sustainability Studies; and Vanessa Casado Perez, Texas A\&M University for their useful comments on an earlier version. I am also grateful for the comments of participants that I have received on the paper during the conference Climate Change, the Sustainable Development Goals and the Law in the Context of Pandemic Recovery, held at University of Cambridge in November 2021. All views and errors are my own.

${ }^{1}$ Bundesverfassungsgericht [BVerfG] [Federal Constitutional Court], Mar. 24, 2021, Case No. BvR 2656/18/1, BvR 78/20/1, BvR 96/20/1, BvR 288/20, http://www.bverfg.de/e/rs20210324_1bvr265618en.html (hereinafter Neubauer). See Bundesverfassungsgericht [BVerfG] [Federal Constitutional Court], Constitutional Complaints Against the Federal Climate Change Act Partially Successful, Press Release No. 31/2021, (Apr. 29, 2021), https://www.bundesverfassungsgericht. de/SharedDocs/Pressemitteilungen/EN/2021/bvg21-031.html.

${ }^{2}$ See e.g. André Nollkaemper, Shell's Responsibility for Climate Change: An International Law Perspective on a Groundbreaking Judgment, VerfassungsbloG: On MATters CONSTITUTIONAL (May 28, 2021), https://verfassungsblog.de/ shells-responsibility-for-climate-change/.

(c) The Author(s) 2022. Published by Cambridge University Press on behalf of the German Law Journal. This is an Open Access article, distributed under the terms of the Creative Commons Attribution licence (https://creativecommons.org/licenses/by/4.0/), which permits unrestricted re-use, distribution, and reproduction in any medium, provided the original work is properly cited. 
the world, ${ }^{3}$ and it has already attracted considerable attention. In this case, the complainants alleged that the German government had failed to introduce a legal framework that is sufficient to swiftly reduce greenhouse gases and to limit the increase in global temperature to well below $2^{\circ} \mathrm{C}$, and preferably to $1.5^{\circ} \mathrm{C}$, compared to pre-industrial levels as stipulated in the 2015 Paris Climate Agreement. Scientists are agreed, and States have accepted in principle, that any temperature increase above these thresholds could lead to dangerous tipping points with unforeseeable consequences for the climate. The complainants further claimed that the reduction of $\mathrm{CO}_{2}$ emissions specified in the Federal Climate Protection Act-fifty-five percent reduction by 2030 from 1990 levels - would be insufficient to meet Germany's obligations under the Paris Climate Agreement and to stay within the remaining $\mathrm{CO}_{2}$ budget, also contesting the fact that the Act does not make provision for $\mathrm{CO}_{2}$ reduction measures beyond 2030. They further sought to question the Act's measures to achieve emission-reduction targets through emission trading schemes internationally. ${ }^{4}$

The constitutional dimension of the judgment lies in the complainants' contention that certain provisions of the Federal Climate Protection Act are incompatible with some of their fundamental rights guaranteed in the German Basic Law, and that these provisions are therefore unconstitutional. The constitutional complaint specifically derives from the State's duties of protection arising from the rights to life, physical integrity and personal freedom, ${ }^{5}$ the right to property, ${ }^{6}$ and the right to a future consistent with human dignity (menschenwürdige Zukunft) and its associated right to an ecological minimum standard of living (ökologisches Existenzminimum). ${ }^{7}$ The complainants rely on their fundamental freedoms more generally with regard to obligations to reduce $\mathrm{CO}_{2}$ emissions for the period after $20300^{8}$

In its judgment delivered on April 29, 2021, the Constitutional Court unanimously declared the Federal Climate Protection Act partly unconstitutional because it does not sufficiently protect people against future infringements and limitations of freedom rights in the wake of gradually intensifying climate change. ${ }^{9}$ By recasting climate protection in constitutional terms, as it did, and by relying on scientific assessments and projections of, among others, the Intergovernmental Panel on Climate Change (IPCC), the Court broadly held there is an obligation on the State to revisit the intertemporal distribution effects of its climate laws and to equitably distribute allowable emissions over time and generations. ${ }^{10}$ In doing so, the Court ordered the legislature to correct and to significantly tighten up the existing climate law provisions, to increase the ambition of these provisions, and to strengthen future mitigation pathways, notably by introducing specific provisions on how the reduction targets for $\mathrm{CO}_{2}$ emissions will be adjusted beyond 2030 .

Although criticized by some on several grounds (and rightly so), ${ }^{11}$ the decision has mostly been lauded by commentators for, among others, its novel approach to constitutional rights-based

\footnotetext{
${ }^{3}$ The other famous example is State of the Netherlands $v$. Urgenda Foundation, Hoge Raad der Nederlanden [Supreme Court of the Netherlands], Dec. 12, 2019, Case No. [2015] HAZA C/09/00456689, (hereinafter Urgenda). See e.g. Chris Backes \& Gerrit van de Veen, Urgenda: The Final Judgment of the Dutch Supreme Court, 17 J. Eur. Environ. Plan. L. 307-21 (2020). For a useful overview of climate litigation research and emerging trends worldwide, see Joana Setzer \& Lisa Vanhala, Climate Change Litigation: A Review of Research on Courts and Litigants in Climate Governance, 10 WIREs: Climate CHANGE 1-19 (2019).

${ }^{4}$ Neubauer, para. 1 .

${ }^{5}$ Grundgesetz [GG] [Basic Law] Article 2(2) (hereinafter Basic Law).

${ }^{6}$ Article 14(1) Basic Law.

${ }^{7}$ These latter rights are derived from Article 2(1) in conjunction with Article 20a, and from Article 2(1) in conjunction with Article 1(1) of the Basic Law.

${ }^{8}$ Neubauer, para. 1 .

${ }^{9}$ See for a general discussion of the decision, Andreas Buser, Of Carbon Budgets, Factual Uncertainties and Intergenerational Equity - The German Constitutional Court's Climate Decision, SocIAL SCIENCE RESEARCH NeTwOrK (SSRN) (Sept. 8, 2021), https://ssrn.com/abstract=3919497.

${ }^{10}$ Neubauer, para. 266.

${ }^{11}$ See e.g. Christian Callies, Das "Klimaurteil" des Bundesverfassungsgerichts: "Versubjektivierung" des Art. 20a GG?, 32 ZEITSCHRIFT FÜR UMWELTRECHT 355-57 (2021). Jannis Krüßmann, Das Bundesverfassungsgericht betrachtet die falschen CO2-Emissionen, JuWissBlog (Nov. 11, 2021), https://www.juwiss.de/100-2021/.
} 
climate protection and its ambition at a time when the legal community and climate activists are exploring all possible legal and other means to address climate change more effectively. ${ }^{12}$ I would suggest that another particularly novel, and hitherto underexplored, aspect of this judgment lies in its tentative embrace of a planetary perspective in the context of the Anthropocene trope. By this I mean the extent to which the Constitutional Court has managed to adjudicate the matter not purely from a traditional and localized domestic context as one would expect $^{13}$, but how the Court (either wittingly or unwittingly), has innovatively managed to embrace a more holistic planetary view of climate science, climate change impacts, planetary justice, planetary stewardship, earth system vulnerability, and global climate law, within the context of a human-dominated geological epoch, to guide its reasoning and findings.

My basic proposal is that Neubauer offers an example of how courts could and should start following a planetary perspective that is grounded in the Anthropocene context when adjudicating matters related to global disruptors such as climate change that affect all earth system processes and everyone-humans and non-humans - everywhere, now and in future. Such a planetary perspective is what the Anthropocene trope ultimately demands, especially to the extent that this trope redirects our attention away from an outdated "environmental protection/management" paradigm, towards earth system-oriented ways of pursuing planetary stewardship. ${ }^{14}$ The Anthropocene, after all:

... focuses the twenty first century challenges for humanity away from resource constraints and environmental impacts toward more fundamental questions. What are the implications of the Anthropocene for the future of humanity in the twenty-first century and beyond? Can we become active, effective stewards of the Earth System, our own life support system? ${ }^{15}$

The rapid rise in climate litigation globally, which evidences an increased reliance on the judiciary to step in to fill regulatory gaps where governments and corporations fail to address global climate change, ${ }^{16}$ suggests that courts can and will play a critically important role in advancing planetary stewardship in the climate context.

In this contribution I explore how the German Constitutional Court has started laying the foundations of such an endeavour through its tentative engagement with fundamental existential questions of survival in the wake of the looming climate crisis, by tracing out some emerging themes and possibilities related to, what one might term, planetary climate litigation. I first discuss what the Anthropocene's planetary context broadly entails and why it has become necessary to start thinking in planetary terms from a law and governance point of view. The next part of the article briefly reveals some of the regulatory implications of a planetary perspective for our social regulatory institutions of law and governance. I then identify and elaborate the planetary aspects of the Neubauer decision. While there may be others, I focus on the Court's reliance on authoritative global climate science; its engagement with the issue of climate targets, tipping points and their relation to constitutional obligations; the Court's engagement with issues of planetary climate justice; and finally, its elaboration of planetary climate stewardship obligations.

\footnotetext{
${ }^{12}$ Henrike Knappe, Justice and the Climate Crisis: Germany's Constitutional Court Rules on Climate Action Legislation, IASS BLOG (May 11, 2021), https://www.iass-potsdam.de/en/blog/2021/05/bundesverfassungsgerichtsurteil-zum-klimaschutzgesetz; Matthias Goldmann, Judges for Future. The Climate Action Judgment as a Postcolonial Turn in Constitutional Law?, Verfassungsblog: On MATters CONSTitutional (Apr. 29, 2021), https://verfassungsblog.de/judges-for-future/; Helmut Aust, Klimaschutz aus Karlsruhe: Was verlangt der Beschluss vom Gesetzgeber?, VeRFASSUNGSBLOG: ON MATTERS CONSTITUTIONAL (May 5, 2021), https://verfassungsblog.de/klimaschutz-aus-karlsruhe-was-verlangt-das-urteil-vom-gesetzgeber/.

${ }^{13}$ The case was after all about the constitutionality of a domestic climate statute.

${ }^{14}$ Frank Biermann, The Future of "Environmental Policy" in the Anthropocene: Time for a Paradigm Shift, 30 EnV. Polit. 61-80 (2021).

${ }^{15}$ Will Steffen et al., The Anthropocene: From Global Change to Planetary Stewardship, 40 AMBIO 739, 741-42 (2011).

${ }^{16}$ See generally Jacqueline Peel \& Hari Osofsky, Climate Change Litigation: Regulatory Pathways to Cleaner Energy, (Cambridge Univ. Press, 2015).
} 


\section{B. The Anthropocene's Planetary Context}

My point of departure in this part is that a planetary perspective has now become the contemporary regulatory context within which to consider and govern interrelated earth system transformations. I propose here, as I have done elsewhere, ${ }^{17}$ that law, lawyers and legal actors such as courts, will need to start embracing a planetary perspective in order for law-and environmental law in particular-to broaden its perspective vis-à-vis the governance challenges of the Anthropocene and, ultimately, for environmental law to remain relevant, useful and effective in the Anthropocene epoch. ${ }^{18}$ I will explore this proposal below, first, by briefly reflecting on the interrelated nature of earth system transformations with a specific emphasis on the climate system. ${ }^{19}$ I will then describe what a planetary perspective entails with reference to three key notions associated with this perspective-and with climate change specifically-namely: Tipping points, planetary boundaries, and the Anthropocene trope.

We live in an era characterized by acute socio-ecological decay that we observe on a daily basis: Weather patterns are rapidly changing with extreme weather events occurring more frequently and causing massive disruptions and displacement; biodiversity is lost at an alarming rate and species are becoming extinct; soil, water and air pollution is rampant, evidenced in particular by the spike in global plastics pollution; and deadly zoonic diseases that are caused by improper human interference in human-animal relationships are on the rise, as the ongoing Covid-19 pandemic suggests. ${ }^{20}$ These ecological disruptions are all deeply intertwined, they impact an increasingly vulnerable living order -which is itself interconnected and interdependent, and they contribute to exacerbate a profoundly uneven world order that is characterized by continuing "forms of eco-violence, economic predation and the unparalleled imposition of precarity on humans and non-humans alike." 21

It is within this context of entangled planetary socio-ecological disruptions that scientists suggest humans are causing irreversible earth system transformations. ${ }^{22}$ These transformations are observable in terms of earth system tipping points that are triggered by human activities. A tipping point "occurs when a small change in forcing triggers a strongly nonlinear response in the internal dynamics of part of the climate system, qualitatively changing its future state." ${ }^{23}$ Examples of climate related tipping points are the continued destruction of the Amazon rainforest, melting of the West Antarctic ice sheet, and disruption of the Atlantic meridional overturning circulation (the Atlantic Ocean's zonally integrated component of surface and deep currents), which could result in massive cascading earth system transformations if ongoing disruptions are not halted. ${ }^{24}$ The idea of tipping points helps to define the climate emergency we are in, to understand the severity of this emergency, and to appreciate that the climate emergency should be characterized as a complex web of interrelated flows

\footnotetext{
${ }^{17}$ See e.g. Louis Kotzé, Earth System Law for the Anthropocene: Rethinking Environmental Law Alongside the Earth System Metaphor, 11 Transnatl. Leg. Theory 75-104 (2020).

${ }^{18} \mathrm{See}$, for more general discussion linking law with the Anthropocene trope, Louis Kotzé (ed.), ENVIRONMENTAL LAW AND Governance For the ANTHropocene, (Hart, 2017); Emily Webster \& Laura Mai (eds.), Transnational ENVIRONMENTAL Law in the Anthropocene: Reflections on the Role of LaW in Times of Planetary Change (Routledge, 2021); Peter Burdon \& James Martel (eds.), The Routledge Handbook on LAW AND THE ANTHropocene (Routledge, forthcoming).

${ }^{19}$ I understand the earth system to mean "a single, planetary-level complex system, with a multitude of interacting biotic and abiotic components, [which has] evolved over 4.54 billion years and which has existed in well-defined, planetary-level states with transitions between them." Will Steffen et al., Stratigraphic and Earth System Approaches to Defining the Anthropocene, 4 Earth's Future 324, 325 (2016), and more generally, Will Steffen et al. (eds.), Global Change AND the Earth System: A Planet Under Pressure (Springer, (2004).

${ }^{20}$ See the most recent authoritative assessment on the state of the planet, UNEP, Global Environment Outlook 6: Healthy Planet Healthy People, (Mar. 4, 2019), https://www.unep.org/resources/global-environment-outlook-6?_ga=2.223443995. 1499091898.1634730974-1924697299.1634730974.

${ }^{21}$ Anna Grear, Legal Imaginaries and the Anthropocene: "Of” and "For", 31 LAW AND CRITIQUe 351, 355 (2020).

${ }^{22}$ Timothy Lenton et al., Climate Tipping Points - Too Risky to Bet Against, 575 Nature 592-95 (2020).

${ }^{23}$ Timothy Lenton, Early Warning of Climate Tipping Points, 1 Nature Climate Change 201, 201 (2011).

${ }^{24}$ Rakhyun Kim, Taming Gaia 2.0: Earth System Law in the Ruptured Anthropocene, 2021 ANTHropocENE REVIEW 1, 2. Emphasis in original.
} 
and cause and effect relationships that are all part of a single intertwined earth system. ${ }^{25}$ We can see through the lens of tipping points that climate change is a complex earth system challenge that involves a complex set of interconnected concerns, actors and impacts that must, therefore, be governed with a critical awareness of the implications of a deeply interconnected earth system. ${ }^{26}$

Closely related to the idea of tipping points is the notion of planetary boundaries, which is another approach to visualizing an integrated earth system and, more specifically, the limits of the earth system. ${ }^{27}$ The planetary boundaries framework suggests it is possible to identify and quantify a set of nine planetary boundaries that are comprehensible only in a complex global system perspective. ${ }^{28}$ These boundaries "define the safe operating space for humanity with respect to the Earth system and are associated with the planet's biophysical subsystems or processes." ${ }^{29}$ If the planetary boundaries are crossed, the chance of maintaining the relatively stable Holocene-like state for human existence (officially still the current geological epoch), significantly diminishes as we step closer to tipping points in earth system processes. ${ }^{30}$

Tipping points and planetary boundaries collectively serve as indicators that we are entering a new post-Holocene geological epoch called the Anthropocene. Still to be officially declared the current geological epoch, in the Anthropocene, human activity is now considered to be the dominant cause of earth system transformation: "[T]he impacts of human activity will probably be observable in the geological stratigraphic record for millions of years into the future, which suggests that a new epoch has begun." 31 The Anthropocene has become the standard narrative to appreciate the extent of human mastery and dominance over a vulnerable living order, while at once providing the context for re-imagining more effective ways to better respond to anthropogenic earth system disruptions such as those caused by $\mathrm{CO}_{2}$ emissions and climate change:

It is effectively an all-encompassing framework that seeks to make sense of the 'earth-system' as a whole: it delineates the planet's natural history and turns it into a new geological period, it specifies the particular influence of human action on the emergence of that epoch, and it accounts for the relationships between the 'scientific' and the 'political' implications of these transformations. ${ }^{32}$

While there is some disagreement on the exact onset date of the Anthropocene, with some tracing its origin to the start of colonial capitalism, ${ }^{33}$ the standard Anthropocene narrative mostly reflects the view that the Industrial Revolution, and more specifically the Great Acceleration, mark the onset of "large-scale human modification of the Earth System, primarily in the form of climate change, the most salient and perilous transgression of [pre-Anthropocene] Holocene parameters." ${ }^{34}$ As earth system scientists say:

\footnotetext{
${ }^{25}$ Lenton et al., supra note 22, at 592.

${ }^{26}$ Will Steffen, A Truly Complex and Diabolical Policy Problem, in The Oxford Handbook of Climate Change AND SocIETY 21 (John Dryzek, Richard Norgaard \& David Schlosberg eds., 2011).

${ }^{27}$ Louis Kotzé \& Duncan French, Staying Within the Planet's "Safe Operating Space”? Law and the Planetary Boundaries, in Research Handbook on Law, Governance and Planetary Boundaries 1 (Duncan French \& Louis Kotzé eds., 2021).

${ }^{28}$ Biermann, supra note 14 , at 66 .

${ }^{29}$ Johan Rockström et al., A Safe Operating Space for Humanity, 461 NATURE 472, 472 (2009). See also Johan Rockström et al., Planetary Boundaries: Exploring the Safe Operating Space for Humanity, 14 Ecol. Soc. 1-32 (2009).

${ }^{30}$ The nine boundaries include: Climate change; rate of biodiversity loss (terrestrial and marine); interference with the nitrogen and phosphorus cycles; stratospheric ozone depletion; ocean acidification; global freshwater use; change in land use; chemical pollution; and atmospheric aerosol loading. It is estimated that we have already crossed four of these boundaries (including the climate boundary), and are approaching others at a rapid rate. Will Steffen et al., Planetary Boundaries: Guiding Human Behaviour on a Changing Planet, 347 SCIENCE 1259855-1- 1259855-10 (2015).

${ }^{31}$ Simon Lewis \& Mark Maslin, Defining the Anthropocene, 519 NATURE 171, 171 (2015).

${ }^{32}$ Daniel Chernilo, The Question of the Human in the Anthropocene Debate, 20 Eur. J. Soc. Theory 44, 45 (2017).

${ }^{33}$ Grear, supra note 21 , at 355.

${ }^{34}$ Andreas Malm \& Alf Hornborg, The Geology of Mankind? A Critique of the Anthropocene Narrative, 1 ANTHROPOCENE REVIEW 62, 63 (2014).
} 
... climate change demonstrate[s] the existence of limits to the rate or magnitude at which humanity can consume the planet's geophysical resources. Furthermore, climate change and the appearance of the ozone hole owing to man-made chemicals are strong evidence that humanity can overwhelm important chemical, physical, and biological processes that modulate the functioning of the Earth System. These unintended consequences on the global life support system that underpins the rapidly expanding human enterprise lie at the heart of the interconnected twenty-first century challenges. ${ }^{35}$

In this view, climate change has evidently become a central marker of the Anthropocene, a characteristic feature of the Anthropocene narrative, and one of the most urgent existential planetary concerns, which, I will argue below, can only be governed by means of a planetary approach wherein law plays a central role.

\section{Law and a Planetary Perspective}

In this part I explore what some of the implications of a planetary perspective could be for law, lawyers and courts, by situating the discussion within the broader framework of earth system governance and earth system law. ${ }^{36}$ At the most general level it can be said that the rise of the Anthropocene narrative and its associated terminologies such as tipping points and planetary boundaries has provoked a major shift in how we perceive and understand human impacts on planet Earth. This shift has scaled up and redirected our attention away from a localized "environmental" context to a planetary context, as it were. As Biermann says:

... more recent [system] perspectives emphasize instead the complete integration of human and non-human agency in complex socio- ecological systems, from local scales - such as forests or water bodies- up to regional scales, such as the Alpine region, and the entire earth system. A socio-ecological system perspective breaks down conceptual barriers between humans and their 'surroundings' and integrates them in a complex understanding where agency is diffuse, interactions are dynamic, and boundaries become blurred. ${ }^{37}$

A planetary perspective therefore offers an opportunity to see and understand that everything is interconnected, that cause-and-effect relationships exist, and that what we do in our own backyards has a much more widely diffused impact than we thought possible. Humans do not merely cause "air pollution" when we drive fossil fuel powered automobiles in the cities where we live. Our collective behavior is forcing global climate tipping points and pushing us across the climate planetary boundary. All of this leads to massive earth system transformations, and ultimately, to planetary integrity being negatively impacted. Some already observe that "the risk of irreversible transformation on a planetary scale could be imminent ... Humanity is not simply standing on a precipice ... but rather stumbling towards it. We may fall at any moment, which will mark an irreparable rupture in time." ${ }^{38}$

The progression from "environmental" to "planetary" thinking heralds nothing less than a long overdue paradigm shift. ${ }^{39}$ It invites us to consider that earth system transformations, while obviously "ecological", are also caused by human-driven predatory paradigms and practices that impact the living order, such as slavery, appropriation, colonialism, extractivism, neoliberal

\footnotetext{
${ }^{35}$ Steffen et al., supra note 15 , at 740 .

${ }^{36}$ See e.g. Frank Biermann, Earth System Governance: World Politics in the Anthropocene (2014); Louis Kotzé \& Rakhyun Kim, Earth System Law: The Juridical Dimensions of Earth System Governance, 1 EARTH SYSTEM GOVERNANCE 1-12 (2019).

${ }^{37}$ Biermann, supra note 14 , at 64 .

${ }^{38} \mathrm{Kim}$, supra note 24 , at 2 (emphasis in original).

${ }^{39}$ I have argued elsewhere that this paradigm shift, when considered in the context of the Anthropocene trope, could even inaugurate a global constitutional moment for law and governance. Louis Kotzé, The Anthropocene's Global Environmental Constitutional Moment, 25 Y. INTL. ENV. L. 24-60 (2014).
} 
developmentalism and corporate ravaging in pursuit of profit for a privileged few. ${ }^{40}$ We can now appreciate that earth system transformations also have a clearly intertwined social dimension, notably to the extent that the Anthropocene's planetary context illuminates the "agentic entanglement [of humans] with a planetary field of radically distributed, multiplicitous agentic forces." 41 The agentic entanglement that characterizes the planetary context, ironically (and tragically) means that the so-called "fate of humanity", will be determined as much by planetary integrity and the extent to which a stable earth system can support life, as it will be by humanity itself. This much is already clear from the extent to which anthropogenic climate change is affecting planetary integrity, and the continued path dependent and unambitious efforts undertaken by States and their corporations to address the climate emergency. The lackluster outcomes of the United Nations Climate Change Conference (COP26) held in Glasgow in November 2021 is a case in point. ${ }^{42}$ Marked as it was by lofty ideals and stirring rhetoric, there were few concrete undertakings by States to enable an urgent pursuit of ambitious regulatory interventions that are commensurate with, and fully responsive to, the climate crisis.

While the ecological aspects and implications of earth system transformations are articulated by earth system science-based frameworks such as tipping points and planetary boundaries, the social aspects and regulatory consequences of earth system change are revealed through emerging social science-based notions such as earth system governance and earth system law. These seek to translate, as it were, insights of earth system science into the social regulatory/governance domain. The mere fact that these notions are evolving suggests a rising awareness of the need to better link earth system science to the social world and its regulatory institutions, including law, that are aimed at steering human behaviour in one direction or another.

Earth system governance is concerned with governing complex earth system challenges at the earth system or planetary scale of governance, ${ }^{43}$ and is defined as:

... the sum of the formal and informal rule systems and actor-networks at all levels of human society that are set up in order to influence the coevolution of human and natural systems in a way that secures the sustainable development of human society-that is, a development that meets the needs of present generations without compromising the ability of future generations to meet their own needs. ${ }^{44}$

Intimately related to earth system governance from which it takes its cue, earth system law has been proposed as a new juridical epistemic framework that can guide interrogations regarding the difficulties posed to law in responding to intertwined earth system governance challenges and ultimately, as a roadmap for law to become more sensitive to and reflective of the functioning of the earth system and the multiple complex governance implications of a coupled earth system. ${ }^{45}$ Earth system law is defined as:

\footnotetext{
${ }^{40}$ Sam Adelman, Epistemologies of Mastery, in ReSEARCH HANDBOOK ON HuMAn Rights AND the EnVIRONMENT 9 (Anna Grear \& Louis Kotzé eds., 2015).

${ }^{41}$ Grear, supra note 21 , at 358.

${ }^{42}$ Glasgow Climate Change Conference - October-November 2021, United NATiOns Framework Convention on Climate CHANGE (UNFCCC) (2021), https://unfccc.int/conference/glasgow-climate-change-conference-october-november-2021.

${ }^{43}$ Sarah Burch et al., New Directions in Earth System Governance Research, 1 EARTH SYSTEM GovernANCE 1-18 (2019).

${ }^{44}$ Frank Biermann, "Earth System Governance" as a Crosscutting Theme of Global Change Research, 17 GLOB. ENVIRON. CHANGE 326, 329 (2007).

${ }^{45}$ See for an overview Louis Kotzé et al., Earth System Law: Exploring New Frontiers in Legal Science, 9 EARTH SYSTEM GOVERNANCE (forthcoming 2021); Louis Kotzé \& Rakhyun Kim, Exploring the Normative, Transformative and Analytical Dimensions of Earth System Law, 50 Environ. Policy L. 457-570 (2020); Laura Mai \& Emille Boulot, Harnessing the Transformative Potential of Earth System Law: From Theory to Practice, 9 EARTH System Governance 1-12 (2021); Marie-Catherine Petersmann, Sympoietic Thinking and Earth System Law: The Earth, its Subjects and the Law, 9 EARTH System Governance 1-8 (2021); Joshua Gellers, Earth System Law and the Legal Status of Non-Humans in the Anthropocene, 7 Earth System Governance 1-8 (2021); Harro van Asselt, Governing Fossil Fuel Production in the Age
} 
... an innovative legal imaginary that is rooted in the Anthropocene's planetary context and its perceived socio-ecological crisis. Earth system law is aligned with, and responsive to, the Earth system's functional, spatial and temporal complexities; and the multiple Earth system science and social science-based governance challenges arising from a no-analogue state in which the Earth system currently operates. Earth system law therefore seeks to respond to the Earth system's instability and unpredictability through a continuous norm development process that drives meaningful transformations as well as interdisciplinary learning and deliberation. ${ }^{46}$

One can already observe the emergence of discussions and terms that seek to translate a planetary perspective into the social regulatory domain on the back of these two epistemic frameworks. One example is "planetary justice", which seeks to re-situate justice and equity within a planetary context by connecting it with global change and earth system transformations. ${ }^{47}$ The idea of planetary justice is, at least terminologically, broader than the more established notion of "environmental justice", ${ }^{48}$ which "brings problematic connotations of a nature-human or person-environment dichotomy that does not capture the integrated character of socio-ecological transformations that stands at the centre of the current Anthropocene debate." ${ }^{49}$ Planetary justice instead departs from the planetary scale, from the need for planetary society-nature integration and the need for nonbinary system thinking. It reflects "the intertwined nature of the earth system in the Anthropocene where social and ecological systems have become inseparable and where obligations are owed to nonhuman entities as well." ${ }^{\text {V0 }}$ Viewing justice through a planetary lens allows us to identify earth system risks that impact equity and justice considerations, such as climate change that affects all present and future human and non-human beings everywhere, and to consolidate and to move towards a deeper understanding of intergenerational justice, intragenerational justice for particularly vulnerable segments of society such as young and poor people, justice in relation to adaptation and mitigation strategies, and interspecies justice. ${ }^{51}$

Another example of law's recognition of the social aspects of earth system transformations is "earth system vulnerability", where the concept of vulnerability, as it has been used in the human rights law context, ${ }^{52}$ has been expanded to apply to the entire earth system, including earth system processes and present and future human and non-human beings. ${ }^{53}$ Earth system vulnerability propagates the insight that "we" (the entire earth system and its living order) are all vulnerable in the Anthropocene, notably by showing that the Anthropocene's powerful Promethean human is also a vulnerable subject. ${ }^{54}$ Anthropos is vulnerable because it impacts earth system stability to

of Climate Disruption: Towards an International Law of "Leaving it in the Ground", 9 EARTH System GOVERNANCE 1-9 (2021).

${ }^{46}$ Rakhyun Kim \& Louis Kotzé, Planetary Boundaries at the Intersection of Earth System Law, Science and Governance: A State-of-the-Art Review, 30 RECIEL 3, 13 (2021).

${ }^{47}$ Frank Biermann \& Agni Kalfagianni, Planetary Justice: A Research Framework, 6 EARTH System GovernanCE 1-11 (2020); Colin Hickey \& Ingrid Robeyns, Planetary Justice: What Can We Learn from Ethics and Political Philosophy?, 6 EARTH SySTEM GOVERNANCE 1-8 (2020).

${ }^{48} \mathrm{See}$, among the rich literature on environmental justice, Sumudu Atapattu, Carmen Gonzalez \& Sara Seck eds., THE Cambridge Handbook of Environmental Justice and Sustainable Development (Cambridge Univ. Press, 2021).

${ }^{49}$ Biermann \& Kalfagianni, supra note 47 , at 2.

${ }^{50} \mathrm{Id}$.

${ }^{51}$ Biermann, supra note 14, at 68; Sara Seck, A Relational Analysis of Enterprise Obligations and Carbon Majors for Climate Justice, 11 Oñati Socio-Legal Series 254-84 (2021).

${ }^{52}$ See e.g. Martha Fineman \& Anna Grear (eds.), Vulnerability: Reflections on a New Ethical Foundation For LaW AND Politics (2013).

${ }^{53}$ Louis Kotzé, The Anthropocene, Earth System Vulnerability and Socio-Ecological Injustice in an Age of Human Rights, $10 \mathrm{~J}$. Hum. Rights Environ. 62-85 (2019).

${ }^{54}$ Angela Harris, Vulnerability and Power in the Age of the Anthropocene, 6 WASH. \& LEe J. ENERGy, Climate, \& ENVIRON. 98-161 (2014). 
such an extent that the quality and longevity of all life on Earth are being jeopardised, its own included. The notion of earth system vulnerability relates to that of planetary justice insofar as it calibrates the idea of universal vulnerability in the Anthropocene by critical attention to profound patterns of differentially distributed vulnerability, where women, children, poor people, and future generations whose well-being depends on our present choices and actions, are particularly vulnerable. ${ }^{55}$ Importantly, earth system vulnerability also shows us that these differentially distributed patterns of vulnerability do not exclusively apply to humans. Instead, because it relates to the entire earth system, including its human-social and ecological elements, an all-inclusive earth system vulnerability perspective responds, conceptually, to the vulnerability of non-human entities and to the interdependent nature of human-non-human systems. In sum then, earth system vulnerability is a concept that potentially more fully embraces the social-human and ecological elements of the earth system within the legal context of vulnerability and human rights law. It does so by explicitly emphasising the stakes of the Anthropocene and the fact that human vulnerability is ontologically intertwined with non-human vulnerability. ${ }^{56}$ The idea of earth system vulnerability is already finding traction in, for example, debates on how company law has failed human rights protection in the context of earth system limits. ${ }^{57}$

As far as our evolving approach to and engagement with global sustainability governance are concerned, the foregoing discussion points to an important turn, even a paradigm shift, that marks a timely progression from the "environmental" to the "planetary" context. I agree with Biermann that "in times of global climate emergencies and earth-system transformations there is no need to tear down an 'environmental policy' infrastructure that has been built over fifty years." ${ }^{8}$ Yet, it must at once be acknowledged that:

... major reforms in discursive framings, institutional arrangements and policy approaches are also needed to cope with the novel challenges of earth system transformation. We need ... new approaches to deal with the injustices of our economic system and the challenges to our democracies that come with global change and earth system transformation; and institutional realignments to prepare for the worst impacts of earth system transformations that we cannot stop. ${ }^{59}$

While this paradigm shift towards a planetary perspective will likely take time to embed itself in society, science and our social regulatory institutions, the implications of such a shift for governance more generally, and for law specifically, including law's agents and actors such as courts and legislatures, are as wide ranging as they are potentially profound, especially in the context of climate change. Worth quoting in full, Grear says:

It is painfully obvious that the law has not yet delivered an adequate response to the urgent problem of climate change. Indeed, finding an adequate response to climate change presents a challenge of unprecedented global complexity for legal systems ... There is a profound and counterproductive discrepancy between the complexity of the climate system as part of a living ontological plane, and law's fundamentally fragmentary responses, which remain locked (in the main) within path-dependent priorities, boundaries and disciplinary

\footnotetext{
${ }^{55}$ Anna Grear, Deconstructing Anthropos: A Critical Legal Reflection on "Anthropocentric" Law and Anthropocene "Humanity", 26 LAW \& CRIT. 225-49 (2015); Prakash Kashwan et al., Planetary Justice: Prioritizing the Poor in Earth System Governance, 6 EARTH SySTEM GOVERNANCE 1-5 (2020).

${ }^{56}$ See also Anna Grear, The Vulnerable Living Order: Human Rights and the Environment in a Critical and Philosophical Perspective, 2 J. Hum. Rights Environ. 23, 42 (2011).

${ }^{57}$ Beate Sjåfjell, How Company Law Has Failed Human Rights-And What to Do About It, 5 Bus. Hum. RigHTS J. 1-21 (2020).

${ }^{58}$ Biermann, supra note 14 , at 73 .

${ }^{59} I d$. at 75 .
} 
commitments ... Legal thought, moreover, has a deep tendency to deploy certain conceptual structures: binaries; reductionisms; atomistic, linear views of causation; taxonomies; separative, bounded domains; territorial jurisdictional parameters, and so forth - none of which fit well with the amorphous complexity of climate change. [Such] tendencies, if anything, tend to exacerbate law's inadequate systemic grasp of the challenges. ${ }^{60}$

Law and lawyers will therefore have to start re-imagining climate law alongside an earth system perspective, and the emerging frameworks of earth system law and earth system governance have already begun tracing out, admittedly mostly at a conceptual level, some of the directions of such a re-imagination. More importantly for present purposes, a planetary re-imagination of climate law, whether it is done alongside the foregoing frameworks or not, will have to involve courts as creative judicial actors that have the power to innovatively steer the development of climate law into one direction or another. The next part explores how the German Constitutional Court has already started contributing, at a far more practical level, to the re-imagination of climate law alongside a planetary perspective in the Neubauer decision.

\section{A Planetary Reading of Neubauer}

It is difficult to determine, based purely on a literal reading of the Neubauer decision, whether the Karlsruhe Court embraced a planetary perspective. On the one hand, the judgment does refer to "earth system", "tipping points", and even "vulnerability" on a few occasions, which might suggest the Court's receptivity of a planetary perspective. But on the other hand, it does not include any specific reference to the Anthropocene, or the terms "planet(ary) boundary/context/perspective/ level". While not entirely unimportant, as we shall see in part D.II below, such a superficial assessment based on the occurrence of "planetary" terms in the judgment leaves us neither here nor there. I suspect the answer to the question about the extent to which the Court embraced a planetary perspective is more nuanced and lies hidden slightly deeper in the Court's argumentation. In what follows, I explore the judgment in search of those instances where the Court explicitly, but mostly implicitly as we shall see, embraced a planetary perspective.

\section{Authoritative Global Climate Science}

While other courts have also relied on climate science to guide and bolster their arguments and to justify their decisions, ${ }^{61}$ the German Constitutional Court's engagement with climate science was exceptionally extensive and innovative. Such thorough engagement is illustrative of a deeper appreciation of the value of authoritative climate science, the global context within which climate science is produced as part of the earth system science discipline, and the relevance and value of climate science for mediating a domestic climate law dispute. In a lengthy analysis spanning several pages, the Court fully immerses itself in the "factual background of anthropogenic climate change, its consequences and the associated risks." ${ }^{62}$ It does so by relying on assessments of the IPCC, an intergovernmental committee that collects and scientifically evaluates peer reviewed findings of earth system science-based climate studies from around the world. ${ }^{63}$ Although not

\footnotetext{
${ }^{60}$ Anna Grear, Towards 'Climate Justice'? A Critical Reflection on Legal Subjectivity and Climate Injustice: Warning Signals, Patterned Hierarchies, Directions for Future Law and Policy, 5 J. Hum. Rights Environ. 103, 104-05 (2014).

${ }^{61}$ See, for example, Urgenda. Benoit Mayer, Milieudefensie v Shell: Do Oil Corporations Hold a Duty to Mitigate Climate Change?, EJIL:TALK! (June 3, 2021), https://www.ejiltalk.org/milieudefensie-v-shell-do-oil-corporations-hold-a-duty-to-mitigate-climatechange/.

${ }^{62}$ Neubauer, para. 16.

${ }^{63}$ Frank Oldfield \& Will Steffen, Anthropogenic Climate Change and the Nature of Earth System Science, 1 ANTHROPOCENE REVIEW 70-75 (2014).
} 
entirely neutral, unpolitical, or even uncontroversial for that matter, ${ }^{64}$ its reports are generally accepted to reflect "scientific consensus on climate science". ${ }^{65}$ This serves to guide States to set climate goals and to provide for a range of climate governance mechanisms in their international, regional, and domestic climate laws that - must ideally — correlate with the level, depth, and ambition of regulatory interventions that climate science suggests would be necessary to address climate change sufficiently and effectively. ${ }^{6}$ Obviously, nothing prevents domestic-or othercourts from also relying on the work of the IPCC to determine whether there is such a correlation between science and climate laws, which is precisely what the Constitutional Court did in this case.

The Court considered the IPCC's assessments sufficiently authoritative to "present the state of scientific research on climate change in a comprehensive and objective manner, thereby providing a basis for science-based decisions." 67 It drew on the IPCC's "virtually unanimous scientific opinion", which was sufficient to convince it that "the rapid acceleration of global warming that is currently observable in comparison with historical levels is essentially due to the change in the material balance of the atmosphere caused by anthropogenic emissions." 68 Such an endorsement and conclusion show that the Court was more than willing to rely on the broader discipline of earth system science which, specifically in the IPCC and broader climate change context, is concerned with questions focused on "changes through time in systems of immense complexity, with many feedbacks and non-linear interactions, and no simple cause and effect relationships." ${ }^{\circ}$ Why is this important for the planetary context described above?

The Court's reliance on the IPCCs' work signals its endorsement of a body of climate science that has a very distinct global character and that has been collated by a respected international institution legitimately constituted by States around the world, and in which numerous scientists spanning the globe are involved with. While the Court also extensively, and correctly so, referenced domestic scientific reports and assessments focusing on climate change in Germany (also discussed below) ${ }^{70}$ it was very much prepared to use the IPCC's work for the purpose of serving as the larger scientific context for its reasoning, and as the context within which to understand domestic climate change impacts. In doing so, the Court managed to open up a dialogue of sorts between global and domestic climate science, where the one informs the other, and where both shape the broader context within which the Court has to make a legal determination.

While this indicates the Court's embrace of a planetary scientific perspective when it comes to grounding and legitimising its view on the global state of climate change, it also suggests that an earth system science perspective had a role to play in the Court's assessment of domestic climate law: the earth system science context shaped, at least to some extent, the legal context within which

\footnotetext{
${ }^{64}$ The IPCC has been described as the "politically favoured means of climate change knowledge assessment." Mike Hulme \& Martin Mahony, Climate Change: What Do We Know About the IPCC?, 34 Prog. Phys. Geogr. 705, 706 (2010) (emphasis added).

${ }^{65}$ Naomi Oreskes, The Scientific Consensus on Climate Change, 306 SCIENCE 1686 (2004).

${ }^{66}$ Importantly, the IPCC does not set the climate goals in the Paris Climate Agreement or elsewhere. That is the prerogative of a political process driven by inter-governmental climate negotiations and domestic legal processes. What the IPPC does is to offer state-of-the-art scientific surveys of climate research that has been conducted globally: "The IPCC is the most important source of scientific, technical and socioeconomic information on climate change for UNFCCC [United Nations Framework Convention on Climate Change]. It plays a central role in preparing regular assessment reports of published scientific information on climate change and in communicating these assessments to the Convention." Conference of the Parties to the Convention on Biological Diversity, Working Relationship Between the United Nations Framework Convention on Climate Change and the Intergovernmental Panel on Climate Change, UNEP/CBD/COP/11/INF/14 (Sept. 17, 2012).

${ }^{67}$ Neubauer, para. 17.

${ }^{68}$ Neubauer, para. 18.

${ }^{69}$ Oldfield \& Steffen, supra note 63, at 72.

${ }^{70}$ See e.g. Sachverständigenrat für Umweltfragen, Demokratisch regieren in ökologischen Grenzen -Zur Legitimation von Umweltpolitik (June 2019); Umweltbundesampt, Klima und Treibhauseffekt (2020); Umweltbundesampt, Vulnerabilität Deutschlands gegenüber dem Klimawandel (2015); Guy Brasseur, Daniela Jacob \& Suanne Schuck-Zöller (eds.), Klimawandel in Deutschland: Entwicklung, Folgen, Risiken und Perspektiven (2017). See Neubauer, paras. 24-30.
} 
the Court considered the constitutionality of the Federal Climate Protection Act. I would suggest that this is a tangible example of how judicial processes could enable the possibility of law being shaped, if not entirely re-imagined, by a planetary-focused scientific perspective that lies at the heart of paradigms such as earth system law and earth system governance.

\section{Tipping Points, Climate Targets and Constitutional Obligations}

The idea of climate tipping points has its origins in earth system science. As was the case with its full embrace of authoritative global climate science, the Court did not shy away from extensively engaging with the notion of tipping points. This is perhaps the Court's most explicit attempt to understand climate change within a planetary context as an interconnected, complex, and multiscalar earth system phenomenon with many cause-and-effect relationships and varied socio-ecological impacts, which it explores in significant detail.

The Court identifies three climate tipping points, namely the impacts of climate change on Earth's melting ice masses and the resultant sea level rise; disruption of the Atlantic meridional overturning circulation, which will have "a major impact on weather systems in Europe, North America and elsewhere"; and destruction of the Amazon rainforest. ${ }^{71}$ Displaying a remarkable appreciation of earth system dynamics in the context of tipping points, the Court says:

Tipping elements are components of the Earth system that have special significance for the global climate and which, when placed under increasing stress, undergo abrupt and often irreversible change ... Minor perturbations in a relevant environmental parameter ... can cause these tipping elements to transition into a qualitatively different state if the parameter value is already close to a critical point, the tipping point. Tipping elements can also interact with one another ... It cannot be ruled out that a cascading series of such interactions could transform the Earth system. ${ }^{72}$

Its detailed reflection on interrelated tipping points leads the Court to analyse, in an equally meticulous manner, the range and extent of climate change impacts in Germany specifically. It does so by reflecting again and again on the interconnected nature of the climate system as part of the larger earth system, and how global climate change impacts Germany. ${ }^{73}$ In this respect the Court skilfully manages to avoid the "bordered" geographical, jurisdictional and interpretative trap occasioned by inward-looking parochialism. With its thorough engagement with earth system science, the Court instead embraces a much broader systems understanding of causally interconnected earth system processes that are not confined - and can never be confined-by country borders and national legal systems, enabling as this does, an opportunity to come to terms with the nuts and bolts of the climate system and global climate change impacts.

The Court concludes that "[A]s things presently stand, the only way to significantly slow down human-induced climate change is by reducing $\mathrm{CO}_{2}$ emissions." "4 It acknowledges that negative emission technologies such as carbon dioxide removal and carbon capture and storage might play a role in limiting or removing $\mathrm{CO}_{2}$, but it is also cognisant of the fact that "negative emission technologies are currently regarded as difficult to implement, at least on a larger scale. There are considerable restrictions and concerns regarding economic viability, technical feasibility and international coordination, as well as in terms of the social impacts and, above all, the emerging ecological risks." 75 The Court's scepticism is very much in line with recent concerns of some earth system governance scholars about the safety of such technologies, including also solar geoengineering, and their unpredictable future impacts. ${ }^{76}$ This signifies the Court's appreciation that

\footnotetext{
${ }^{71}$ Neubauer, paras. 20-21.

${ }^{72}$ Neubauer, para. 21.

${ }^{73}$ Neubauer, paras. $24-30$.

${ }^{74}$ Neubauer, para. 31.

${ }^{75}$ Neubauer, para. 33 .

${ }^{76}$ Frank Biermann, It Is Dangerous to Normalize Solar Geoengineering Research, 595 NATURE 1 (2021); Frank Biermann et al., Solar Geoengineering: The Case for an International Non-use Agreement, WIREs Climate Change (forthcoming).
} 
a precautionary approach should be followed when considering using such technologies, including a thorough consideration of the ongoing uncertainty surrounding the impacts of climate technologies on the earth system.

Considering the real possibility that climate tipping points might be triggered soon, and the range and extent of devastating impacts this will have on the earth system, the only rational solution for the climate emergency is, as the Court says, to reduce $\mathrm{CO}_{2}$ emissions. Any such reductions can only occur when human behaviour changes, and one of the most effective ways to change human behaviour is through the regulatory institution of law. Most climate laws, including the Paris Climate Agreement, the German Federal Climate Protection Act, and other regional and domestic climate laws, follow the so-called target approach that seeks to limit climate change to an upper boundary of temperature increase. Pittel explains that the target approach involves a logic whereby only a certain amount of greenhouse gasses may be released up until a specific temperature limit is reached-for example, $2^{\circ} \mathrm{C} / 1.5^{\circ} \mathrm{C}$ as per the Paris Climate Agreement. ${ }^{77}$ The specification of these fixed temperature targets is guided by, among others, earth system science frameworks such as the planetary boundaries theory, and in this case, climate temperature targets must ideally be informed by the planetary climate boundary threshold value. ${ }^{78}$ The planetary boundary theory has explicitly been used, notably also in the context of the Anthropocene, by the German Advisory Council on the Environment (Sachverständigenrat für Umweltfragen (SRU)), ${ }^{79}$ the recommendations of which the Court also relies on in addition to that of the IPCC to guide its decision. ${ }^{80}$

Again, the Court never directly mentions planetary boundaries or Anthropocene, but I would suggest that the Court does not actually need to explicitly do so because they have already been indirectly included in its reasoning through its ample reliance on the science-based recommendations of expert committees, such as the SRU, that extensively canvass and utilise these frameworks in their reports that served before the Court. The Court's reliance on a large body of earth system science enables it to adopt a planetary boundaries-based target approach in its decision. The Court considers that "[T]he methodological advantage of using such temperature targets lies in their direct correlation with the effects of global warming, because the mean temperature of the Earth is a core indicator for the state of the Earth system as a whole." 81 That the Court was very much aware that the shape, content and objectives of climate law, and the extent of the legal obligations derived from these laws, will be determined and continuously shaped by the latest scientific research on climate change is clear from its view that:

Art. 20a GG [Grundgesetz] places the legislator under a permanent obligation to adapt environmental law to the latest scientific developments and findings. If the temperature target agreed in Art. 2(1)(a) PA [Paris Agreement] proves inadequate to sufficiently prevent climate change, the obligation arising from Art. 20a GG to involve the international level in seeking to resolve the climate problem is also modified. In particular, attempts would have to be made to reach more stringent international agreements. On the other hand, any reorientation towards weaker climate goals would have to be justified in the light of Art. 20a GG due to the associated ecological setback ... unless more recent and sufficiently substantiated findings in climate research show that global warming is less potentially damaging than is currently feared. ${ }^{82}$

\footnotetext{
${ }^{77}$ Karen Pittel, The Intertemporal Distribution of Climate Policy Burdens and the Decision of the German Constitutional Court, 5 CESifo Forum 15, 16 (2021). In the case of the Paris Climate Agreement this would be "holding the increase in the global average temperature to well below $2^{\circ} \mathrm{C}$ above pre-industrial levels and pursuing efforts to limit the temperature increase to $1.5^{\circ} \mathrm{C}$ above pre-industrial levels." Paris Climate Agreement, Article 2.

${ }^{78}$ Pittel, supra note 77 , at 16.

${ }^{79}$ See e.g. Sachverständigenrat für Umweltfragen, supra note 70, at 6, where the SRU makes it clear that breaching planetary boundaries must be avoided for the purpose of enabling a "sustainable Anthropocene/nachhaltiges Anthropozän."

${ }^{80}$ See e.g Neubauer, paras. 16.

${ }^{81}$ Neubauer, para. 35 .

${ }^{82}$ Neubauer, para. 211.
} 
Moreover, the legislature is under a permanent constitutional obligation to continuously adapt environmental law in the light of the latest scientific developments and findings. This is the highest and most stringent legal obligation that can possibly exist in a constitutional state (Rechtsstaat) insofar as it mobilizes the constitutional state's full range of constitutional checks and balances that can effectively enforce the German government's constitutional duty to keep its climate laws aligned with state-of-the-art climate science. In addition to elevating climate protection to the constitutional level, this is one of the clearest articulations yet by any court of the mutually supportive and beneficial relationship between global climate science and international and domestic climate law, and of the links between what the science says and the type of legal obligations that should arise from these laws. Climate science must shape the law, and the law must be responsive to state-of-the-art climate science. This is arguably also an implicit endorsement of the recent view that earth system science based planetary boundaries must ideally be translated into legal boundaries:

... effective environmental legislation must at a minimum act as legal boundaries that prevent human activities from reaching and breaching planetary boundaries, defined as the safe space for mankind to operate within ... In other words, legal boundaries must translate the physical reality of a finite world into law and thereby delimit acceptable levels of human activity. ${ }^{83}$

This is significant because it might point to the possible emergence of a new climate law and governance approach that is fully supported by constitutional institutions, and undergirded and shaped by processes of dynamic knowledge creation in the domain of climate and earth system science. Relying on the periodical reports of the IPCC and other respected scientific institutions is one of many possibilities for lawyers - and courts - to ensure that climate laws are actually dynamically designed, interpreted and applied in accordance with dynamic state-of-the-art climate and earth system science.

Apart from illustrating the Court's willingness to engage with earth system science, its exploration of tipping points and the target limit approach also has constitutional significance insofar as it helped to guide the Court's interpretation of Article 20a of the Basic Law. The target limit implies there is a global emissions budget; once it has been exhausted no more emissions are allowed. To this end, the target approach allows the Court to derive maximum permissible emissions for Germany from the remaining global emissions budget, which was a central consideration in its assessment of the extent of climate burdens that will be imposed on future generations. ${ }^{84}$ The Court essentially argued that an increased use of total greenhouse gas emissions by 2030 will disproportionally result in greater restrictions of future freedoms that are linked with the constitutional requirement to protect the climate and achieve climate neutrality. ${ }^{85}$ In other words, "[T]he more emissions currently permitted until 2030, the greater the risk that from 2031 the state will have to intervene more quickly and strongly in fundamental rights." 86 Such an assessment eventually led it to conclude that the constitutional obligation set out in Article 20a of the Basic Law involves both the achievement of climate neutrality and a just and timely transition towards climate neutrality in a way that does not restrict fundamental rights from 2030 onwards in an intergenerational sense; a matter to which I return to in more detail below.

\footnotetext{
${ }^{83}$ Guillaume Chapron, Yaffa Epstein, Arie Trouwborst \& José Vicente López-Bao, Bolster Legal Boundaries to Stay Within Planetary Boundaries, 1 NAT. ECOL. Evol. 1, 1 (2017). See generally, on the relationship between law, governance and planetary boundaries, Duncan French \& Louis Kotzé (eds.), ReSEARCH HANDbook on LAW, Governance AND Planetary Boundaries (2021).

${ }^{84}$ Neubauer, para. 36

${ }^{85}$ See also infra part D.III.

${ }^{86}$ Ralph Bodle \& Stephan Sina, The German Federal Constitutional Court's Decision on the Climate Change Act, ECOLOGIC Institute Berlin Policy Brief, May 10, 2021, at 4.
} 
Through its adoption of the planetary boundary-based target approach, the Court could convincingly link planetary limits that are derived from earth system science with the idea of a global carbon budget by structurally coupling the planetary boundaries-derived $2{ }^{\circ} \mathrm{C} / 1.5^{\circ} \mathrm{C}$ with Article 20a of the Basic Law. ${ }^{87}$ The implication of such a link, Callies believes, is that the German government must ensure where dangerous levels are reached with respect to climate tipping points, that necessary precautionary measures are taken on a continuous basis to stay within a safe distance of the planetary boundaries. ${ }^{88}$ And this is precisely what the Court managed to achieve in its articulation of the government's constitutional obligation with respect to climate change, which includes to equitably distribute what remains of allowable emissions in the carbon budget over time and generations, and to eventually achieve climate neutrality. ${ }^{89}$

Based on the extensive body of climate science that it surveyed, this was the only possible conclusion the Court could come to, as Aust says. ${ }^{90}$ In recognition of the limitations imposed upon it by the separation of powers rule, the Court carefully avoided reading a numerical climate goal into the Basic Law and the Federal Climate Protection Act; such a determination remains the task of the legislature. But the planetary boundary-based target approach nevertheless presented the Court an opportunity to characterize the Federal Climate Protection Act's reference to the Paris Climate Agreement climate goals "as a concretization of constitutional obligations stemming from Art. 20a GG [Grundgesetz] and [the Court] thereby 'uplifted' international obligations between states, to constitutional obligations toward individuals." ${ }^{\text {"1 }}$ Goldmann is therefore correct when he says that "[T] he novelty of this case ... consists in the skillful entanglement of international law and institutions with constitutional law, which provides the basis for the [Constitutional Court's] development of a constitutional temperature brake." 92 I believe that this novel approach was made possible, certainly in part, by the Court's extensive embrace of a planetary perspective that is informed by earth system science, the planetary boundaries and tipping points.

\section{Planetary Climate Justice}

The Court's engagement with aspects of the evolving paradigm of justice in a planetary context, or "planetary justice" discussed above, lies at least at four levels. The first, less intuitive and implicit one, is again the Court's reliance on global climate science to guide its decision. ${ }^{93}$ As we have seen above, although the Court never explicitly says so, its emphasis of the IPCC's assessments as the basis for its decision possibly signals its rational appreciation of the importance of relying on authoritative global climate science where such reliance is necessary for guiding the interpretation of climate laws that allegedly also negatively impact constitutional human rights protection because the laws are deemed inadequate. In this respect I agree with Oldfield and Steffen that "[D]enying the relevance and validity of Earth System science is a highly risky, and possibly catastrophic, approach for humanity to take towards its future"; ${ }^{44}$ especially, as they point out, when considered in the context of climate change and the work of the IPCC. It is risky and possibly catastrophic not to rely on the best available state-of-the-art earth system science when designing, interpreting and applying climate laws, because such an approach could be fundamentally disconnected from what the science tells us about global climate change and its impacts. This, in turn, could render our engagement with climate laws, and even climate laws themselves, incapable of effectively responding to the multiple and varied vulnerabilities of the entire living order (or earth

\footnotetext{
${ }^{87}$ Callies, supra note 11 , at $355-66$.

${ }^{88} I d$.

${ }^{89}$ See also infra.

${ }^{90}$ Aust, supra note 12.

${ }^{91}$ Buser, supra note 9.

${ }^{92}$ Goldmann, supra note 12 .

${ }^{93}$ See also supra part D.I.

${ }^{94}$ Oldfield \& Steffen, supra note 63, at 74 .
} 
system vulnerability) that are occasioned by climate change, including human rights abuses and intergenerational, intrageneration and interspecies injustices. If the scientific consensus is, for example, that climate change will increasingly cause severe floods in Germany-and elsewhere in the world - that impact the rights to life, dignity and property, ${ }^{95}$ among others, then it would be apposite for the legislature to craft laws that can protect people against such human rights infringements.

Second, the same could be said for the Court's cosmopolitan approach in relying on climate science-based international climate law. This sends a strong signal of its endorsement of the principle of "international legal openness" (Völkerrechtsfreundlichkeit) as a method to interpret the provisions of the Basic Law that relate to climate obligations. ${ }^{96}$ The Court's international legal openness points to its willingness to engage in processes associated with the transnationalization of environmental (constitutional) law, which is especially appropriate when adjudicating a legal issue such as climate change that is by its very nature global, or transnational. Transnational environmental law embraces various aspects of environmental law in a transnational regulatory space. It has emerged as an epistemic framework to understand and engage with the place and role of law in an increasingly globalized world order where neither law nor environmental impacts are confined by borders. ${ }^{97}$

In doing so, the Court could capitalise on the rich opportunities that a transnational (constitutional) environmental law approach presents. ${ }^{98} \mathrm{~A}$ transnational approach can contribute to crafting more comprehensive, responsive, representative and ultimately, effective, legal responses to climate change and its multifarious and patterned forms of planetary inequality and injustices that render the entire earth system vulnerable. We already see this occurring within the realm of the expanding area of "transnational climate law". ${ }^{99}$ I have argued elsewhere that transnational (constitutional) environmental law is a contemporary and fit-for-purpose legal approach to regulate human activities in the context of the Anthropocene's interconnected earth system, ${ }^{100}$ especially in a globalised world, where:

The complexity of the governance landscape presents a challenge for both scholars and for policy-makers ... For lawyers, the phenomenon of transnational governance is exciting but also destabilizing. We are not quite as certain today that we know what to count as law or that law is inherently tied to the state. Our methodologies for identifying and constructing law have also started to change. In the world of transnational law and governance, we can no longer simply read law off the statute book or case report. We have to examine multifarious institutional practices as well. ${ }^{101}$

And this is precisely what the Constitutional Court managed to accomplish in Neubauer in the specific context of climate change, especially to the extent that its reliance on international climate law guided its decision on a domestic constitutional dispute that also has transnational implications, especially in a global North-South context as I argue below.

\footnotetext{
${ }^{95}$ The devastating floods in Germany in July 2021 were, according to a recent World Weather Attribution Study, most likely caused as a result of climate change. See Heavy Rainfall Which Led to Severe Flooding in Western Europe Made More Likely by Climate Change, World WeAtHer ATtRiBution, (Aug. 23, 2021), https://www.worldweatherattribution.org/heavy-rainfallwhich-led-to-severe-flooding-in-western-europe-made-more-likely-by-climate-change/.

${ }^{96}$ Goldmann, supra note 12. See generally, on this principle, THERESA AbEND, GRENZEN DER VÖLKERRECHTSFREUNDLICHKEIT (Univeritätsverlag Göttingen) (2019).

${ }^{97}$ Louis Kotzé, The Transnationalization of Environmental Constitutionalism, in RESEARCH HANDBOOK ON Transnational Environmental Law 159 (Veerle Heyvaert \& Leslie-Anne Duvic-Paoli eds., 2020).

${ }^{98}$ Louis Kotzé \& Caiphas Soyapi, Transnational Environmental Law: The Birth of a Contemporary Analytical Perspective, in Research Handbook on Fundamental Concepts of Environmental LaW 82 (Douglas Fisher ed., 2016).

${ }^{99}$ See e.g. Thijs Etty et al., Transnational Climate Law, 7 TEL 191-200 (2018).

${ }^{100}$ Louis Kotzé, Global Environmental Constitutionalism in the AnTHropocene (Hart) (2016).

${ }^{101}$ Jolene Lin \& Joanne Scott, Looking Beyond the International: Key Themes and Approaches of Transnational Environmental Law, 1 TEL 23, 24 (2012).
} 
Third, and more subtly though, Goldmann points out that:

The BVerfG [Bundesverfassungsgericht-Constitutional Court] crucially relies on the expertise provided by the Intergovernmental Panel on Climate Change (IPCC). The reliability of the IPCC, whose working methods the BVerfG recalls in some detail, results not only from its high level of expertise and the wealth of information taken into account. One also has to see it as a function of the international nature of this institution. It ensures multiple perspectives and saves us from the risk of parochialism inherent in a purely national point of view. In this regard, the BVerfG's use of IPCC reports resuscitates the functionalist hope in international institutions as havens of rational discourse, a rare quality in times of societal polarization, spreading autocracy, mistrust in public institutions, and even state-sponsored misinformation. ${ }^{102}$

The mere fact that the Court relied on authoritative global climate science hints at its implicit rejection of false scientific balance and systemically constructed climate denialism and ignorance (also referred to as the process of "manufacturing uncertainty"), ${ }^{103}$ that have become, problematically so, deeply embedded in some sectors of society. These are exemplifiers of the "human capacity for bending rationality in order to accommodate hierarchies of power"; ${ }^{104}$ and they are fuelled by the rise of post-truth politics and extremist populism, radical anti-rationalism, ${ }^{105}$ and a sweeping rejection of rational science and the rule of law. ${ }^{106}$ Such an implicit rejection by the Court is significant when considering justice in a planetary context where the differentially distributed vulnerability of the entire earth system is a central concern. It is, after all, precisely such hierarchies of power, of which climate denialism is an essential part to the extent that it nourishes and expands these hierarchies, that are responsible for causing the massively uneven world order of the Anthropocene. ${ }^{107}$ This world order is characterized by large scale human rights abuses as a result of short-termism, egocentric self-satisfaction, and unrestricted consumption and growth at the expense of the marginalized and oppressed human and non-human world on which it depends to sustain its ultimately unsustainable metabolism. ${ }^{108}$

One example among many is the well-orchestrated efforts of powerful transnational energy corporations, and their use of climate denialism and disinformation campaigns in support of their predatory exploitative practices that cause massive human rights abuses around the globe in the name of economic progress and development: ${ }^{109}$

... corporations are states' most agile, lucrative, profitable and influential agents of 'sustainable' development, as it were. As long as cheap fossil fuels are available to exploit, and corporations fill state coffers by doing so, there are few incentives for governments to force corporations to restrict their socio-ecological destructive activities, to shift their focus to renewable resources, and to take responsibility for the climate injustices they cause.

\footnotetext{
${ }^{102}$ Goldmann, supra note 12 (emphasis added).

${ }^{103}$ See among others David Michaels, Manufactured Uncertainty: Protecting Public Health in the Age of Contested Science and Product Defense, 2006 ANNALs N.Y. ACAD. SCI. 149-62.

${ }^{104}$ Harris, supra note 54, at 142.

${ }^{105}$ Jane Suiter, Post-Truth Politics, Political Insight, (Dec., 2016), at 25-27.

${ }^{106}$ Authoritative science will arguably have to play a more pronounced role in assisting humanity to explore sustainability transformations in the Anthropocene. Roman Seidl et al., Science with Society in the Anthropocene, 42 AMBIO 5, 5 (2014)

${ }^{107}$ Grear, supra note 60 , at $103-33$.

${ }^{108}$ Sam Adelman, The Sustainable Development Goals, Anthropocentrism and Neoliberalism, in SUSTAINABLE Development Global Goals: Law, Theory and Implementation 15 (Duncan French \& Louis Kotzé eds., 2018).

${ }^{109}$ As Walters points out, "multibillion-dollar energy corporations have actively sponsored the voices of opposition to global warming and as such have been described as the 'heart and soul of climate denial' in the US ... Moreover, the powerful and affluent corporate deniers in the US have also attempted to polarise society and actively obstruct policies that seek to protect the environment." Reece Walters, Climate Change Denial: "Making Ignorance Great Again", in IGNORANCE, POWER AND Harm. Critical Criminological Perspectives 163, 171 (Alana Barton \& Howard Davis eds., 2019).
} 
Unsurprisingly then, to date no MEA [multilateral environmental agreement] regulates the environmentally harmful activities of corporations, including under the global climate law regime. $^{110}$

The Court instead fully endorsed the rational science approach despite, and perhaps because of, intensifying scepticism of the IPCC and its work, which is being propagated by disinformation campaigns and conspiracy theories, and supported by "merchants of doubt" such as special interest groups associated with fossil fuel lobbyists, and politically motivated ultra-right wing fear campaigns. ${ }^{111}$ If the judicial endorsement of authoritative planetary-focused climate science also implies a rejection - even if only implicitly —of those predatory paradigms and practices that contribute to and intensify climate injustices and vulnerability at a planetary scale, as I believe they do, then the Constitutional Court has sent a strong signal in support of crafting a scientifically informed legal response that is responsive to earth system vulnerability, and particularly to human rights abuses and injustices associated with global climate change.

Finally, the most obvious aspect of the Court's engagement with matters of planetary justice is its very clear finding on intergenerational justice and equity. ${ }^{112}$ To be clear, the Court did not expand Article 20a of the Basic Law to include any form of fundamental rights for future human and nonhuman generations in the context of climate change. It instead found certain provisions of the Federal Climate Protection Act to be "unconstitutional to the extent that they create disproportionate risks that freedom protected by fundamental rights will be impaired in the future." 13 These provisions "irreversibly offload major emission reduction burdens onto periods after 2030," 114 which means they have a disproportionate intergenerational impact. In the words of the Court,

It follows from the principle of proportionality that one generation must not be allowed to consume large portions of the $\mathrm{CO}_{2}$ budget while bearing a relatively minor share of the reduction effort, if this would involve leaving subsequent generations with a drastic reduction burden and expose their lives to serious losses of freedom - something the complainants describe as an 'emergency stop'. 115

While the focus here was very much on intergenerational justice, I agree with Biermann that it also "raises possibilities for similar arguments of intra-generational justice and a globalist, pro-poor constitutional interpretation". ${ }^{116}$ One sees this in terms of the Court's implicit consideration of intragenerational justice and equity-especially in a North-South context-which is also a key consideration in the larger planetary justice paradigm, as we have seen above. This is not a term that the Court explicitly invokes, but it does reflect on certain aspects of intragenerational justice, notably in its consideration of standing of claimants living outside of Germany. Some of the complainants live in Bangladesh and Nepal; global South countries that the Court itself notes "are particularly vulnerable in a range of different ways to changes in climatic conditions and [that] are directly endangered by ongoing climate change."117 The Court allowed these complainants

\footnotetext{
${ }^{110}$ Louis Kotzé, Louise du Toit \& Duncan French, Friend or Foe? International Environmental Law and its Structural Complicity in the Anthropocene's Climate Injustices, 11 Oñati SocIO-LEGAL SERIES 180, 194 (2021).

${ }^{111}$ Oldfield \& Steffen, supra note 63, at 71.

${ }^{112}$ See generally, on this concept in the legal context, Edith Brown Weiss, Climate Change, Intergenerational Equity, and International Law, 9 VT. J. ENVTL. L. 615-27 (2008); Lynda Collins, Environmental Rights for the Future? Intergenerational Equity in the EU, 16 RECIEL 321-31 (2007).

${ }^{113}$ Neubauer, para. 183.

${ }^{114}$ BVerfG Press Release, supra note 1.

${ }^{115}$ Neubauer, para. 192.

${ }^{116}$ Frank Biermann, Germany's Climate Law Ruled Unconstitutional: First Reflections, BLOG (Apr. 30, 2021), https://www. frankbiermann.org/post/germany-s-climate-law-ruled-unconstitutional-first-reflections.

${ }^{117}$ Neubauer, para. 79.
} 
standing, and justified its liberal locus standi approach with the view that climate change is "a genuinely global phenomenon and could obviously not be stopped by the German state on its own. However, this does not render it impossible or superfluous for Germany to make its own contribution towards protecting the climate." 118 According to Buser, such a "flexible" approach to standing and admissibility of claims demonstrates the Court's willingness to acknowledge that climate change affects everyone, which essentially enabled it to accept a "global actio popularis". ${ }^{119}$

Yet, despite its generous stance on standing, the Court was unwilling to accept that protection duties arising from the Basic Law also create constitutional obligations for the German government vis-à-vis complainants living in Bangladesh and Nepal, and it therefore rejected their claims. ${ }^{120}$ On the one hand, the Court admits that "[I]n their own countries, the complainants are particularly exposed to the consequences of global warming caused by global greenhouse gas emissions. Since greenhouse gas emissions have a global impact, further global warming can only be prevented if all states take climate action. This means that greenhouse gas emissions must be reduced to climate-neutral levels in Germany also." ${ }^{21}$ But on the other hand, and understandably so, "[G]iven the limits of German sovereignty under international law, it is practically impossible for the German state to afford protection to people living abroad by implementing adaptation measures there ... Rather, it is the task of the states concerned to select and implement the necessary measures." ${ }^{122}$ While some are critical of the Court's finding in this regard, ${ }^{123}$ I agree with Bäumler that the Court's acknowledgement of Germany's general obligations to address climate change impacts that also have a global impact, "is a considerable step, and a step in the right direction: the Court acknowledged Germany's responsibilities for its effects abroad, including by taking into account historical and current contributions and capacities. Had Germany not taken any measures, the Court might have confirmed a violation because the effects created abroad provide for a possible link for responsibility and an extraterritorial duty to protect." ${ }^{24}$ After all, and possibly in an effort to underline Germany's role as a good global citizen when it comes to planetary climate stewardship, ${ }^{125}$ the Court noted that "[T]his does not exclude Germany from assuming responsibility, either politically or under international law, for ensuring that positive steps are taken to protect people in poorer and harder-hit countries." 26

Returning to the matter of intergenerational justice, importantly, the Court again came to its conclusion based on its scientifically grounded and informed understanding of what is allowable under the current carbon budget, ${ }^{127}$ and how this allowance will possibly affect the exercise and protection of human rights in future when more severe climate protection measures will need to be implemented to stay within the allowable budget. The Basic Law:

... imposes an obligation to safeguard fundamental freedom over time and to spread the opportunities associated with freedom proportionately across generations. As intertemporal guarantees of freedom, fundamental rights afford the complainants protection against the greenhouse gas reduction burdens imposed by Art. 20a GG [Grundgesetz] being unilaterally

\footnotetext{
${ }^{118}$ Neubauer, paras. $99-100$.

${ }^{119}$ Buser, supra note 9.

${ }^{120}$ Neubauer, para. 174 .

${ }^{121}$ Neubauer, para. 174.

${ }^{122}$ Neubauer, para. 178 .

${ }^{123}$ Jasper Mührel, All that Glitters Is Not Gold: The German Constitutional Court's Climate Ruling and the Protection of Persons Beyond German Territory Against Climate Change Impacts, VÖlKerReChTSBlog: InTERNATIONAL LAW AND INTERnAtional Legal Thought (May, 3 2021), https://voelkerrechtsblog.org/all-that-glitters-is-not-gold/.

${ }^{124}$ Jelena Bäumler, Sustainable Development Made Justiciable: The German Constitutional Court's Climate Ruling on Intraand Inter-generational Equity, EJIL: TALK! (June 8, 2021), https://www.ejiltalk.org/sustainable-development-made-justiciablethe-german-constitutional-courts-climate-ruling-on-intra-and-inter-generational-equity/.

${ }^{125}$ See also part D. IV below.

${ }^{126}$ Neubauer, para. 179.

${ }^{127}$ See supra part D.II.
} 
offloaded onto the future ... In this respect, there is a lack of a legal framework specifying minimum reduction requirements after 2030 that would be suitable for providing orientation and incentives in time for the necessary development of climate-neutral technologies and practices. $^{128}$

The legislator, therefore, must take sufficient precautionary measures to ensure that freedom rights are respected when making a future transition to climate neutrality. The idea of the carbon budget, informed as it is by earth system science, tipping points and planetary boundaries as we have seen above, has again played a role in the Court's constitutional assessment of Germany's climate law. This time, it allowed the Court to justify its determination of the Federal Climate Protection Act's unconstitutionality in intergenerational terms. This is an important example of how a deeper understanding of earth system and climate science makes it possible for a court to innovatively frame its constitutional assessment not only purely in legal terms, but also in the context of state-of-the-art science that highlights temporal planetary justice consequences in the light of carbon budget allowances and limits. Moreover, it is also an example of how legal imagination can become legal reality through judicial creativity. After all, a contested legal principlesoftest of the soft even among international environmental lawyers, as French points out $-{ }^{129}$ has found a home within one of the most revered courts around the globe.

\section{Planetary Climate Stewardship}

Finally, I believe that Neubauer is a concrete example of how a domestic court can become a planetary climate steward. This is significant because the Anthropocene requires a paradigm shift that must see a critical transition away from the current Holocene-based approach of path-dependent "environmental protection", to an approach that enables States, and other social/legal actors such as courts, to become planetary stewards that pursue planetary integrity:

The Anthropocene is a reminder that the Holocene, during which complex human societies have developed, has been a stable, accommodating environment and is the only state of the Earth System that we know for sure can support contemporary society. The need to achieve effective planetary stewardship is urgent. As we go further into the Anthropocene, we risk driving the Earth System onto a trajectory toward more hostile states from which we cannot easily return. ${ }^{130}$

To become planetary stewards, will require of us to redirect our knowledge producing systems towards a better understanding of earth system thinking; to become more sensitive towards the complex multilevel and multi-actor characteristics inherent to earth system governance; and to design new, innovative global/transnational governance institutions, processes and interventions that match "the grand challenge" of earth system decay. ${ }^{131}$ For law specifically, this shift will also involve looking beyond domestic borders and legal and political institutions, in order to address the integrity of the earth system at a planetary scale in a way that embraces diverse

\footnotetext{
${ }^{128}$ Neubauer, para. 183.

${ }^{129}$ In the context of international environmental law, and despite the fact that the principle of intergenerational equity has become more popular and has gained ground in being accepted — or at least supported—by States since he made this assessment in 2005, French correctly points out that "while the interests of future generations has unquestionable symbolism, and one that underpins other concepts such as the principle of sustainable use and the precautionary approach, its own normative status is clearly questionable.” Duncan French, International LaW and Policy of Sustainable Development 61 (Manchester Univ. Press, 2005).

${ }^{130}$ Steffen et al., supra note 15 , at 739.

${ }^{131}$ Uno Svedin, Challenges for Planetary Stewardship at the Entry of the Period of the Anthropocene, in SUSTAINABLE Development, Knowledge Society and Smart Future Manufacturing Technologies 3, 17 (Walter Filho, Arnolds Úbelis \& Dina Bērzina eds., 2015).
} 
knowledge systems that is at once sensitive to multiple and varied earth system vulnerabilities caused by global disruptors such as climate change. Novel paradigms that embrace earth system thinking, such as earth system governance and earth system law, already offer a roadmap that could guide law's role in a transition to planetary stewardship. In short, law, lawyers and courts will have to be sensitive and receptive to the new "planetary" scale of governance in their pursuit of planetary stewardship.

I would suggest that the Constitutional Court's approach in Neubauer shows what could be possible if courts were to embrace the task of becoming planetary stewards themselves, and perhaps more importantly, when they remind other organs of State, such as the legislature, that also they must become planetary stewards in the face of the Anthropocene's climate predicament. The Court's implicit embrace of a planetary stewardship role is, again, evidenced by its willingness to draw on the rich body of earth system science and its reliance on international law in its decision. This shows its appreciation of the importance of opening up to the planetary perspective when crafting the general interpretative context within which the law must be evaluated. This issue has been extensively canvassed above.

Another more explicit consideration is the very clear way in which the Court has managed to articulate and stress the importance of the need to govern climate change globally, and for States to cooperate at the international level in this regard. The Court is clear that the pathway towards climate neutrality can only be successful if it also involves international cooperation that is embedded in an international law and inter-State context. At the same time, the lack of other States to act is not an excuse for Germany's reluctance to tackle climate change within and outside German boarders; on the contrary, "the particular reliance on the international community gives rise to a constitutional necessity to actually implement one's own climate action measures at the national level - in international agreement wherever possible." ${ }^{32}$ The Court notes that:

In requiring that the natural foundations of life also be protected for future generations, Art. 20a GG [Grundgesetz] makes it obligatory to pursue a goal that the national legislator is not capable of reaching on its own but can only achieve through international cooperation. This is due to the physical realities of climate change and climate action. The problem of climate change and the (legal) activities involved in its prevention are genuinely global in nature ... No state can stop global warming on its own. ${ }^{133}$

This amounts to nothing less than the articulation by the Court of a state philosophy of international involvement (Staatsphilosophie des international eingebundenen), ${ }^{134}$ that must prevail among States that assume collective responsibility to address climate change, not only in their own territories, but also globally. I would also add that the Court's exceptionally strong emphasis on the need for a global partnership approach to tackle a deeply interconnected global phenomenon such as climate change, is as much an illustration of its appreciation of its own planetary stewardship role in formulating and judicially imposing a constitutional obligation on the State to pursue planetary climate stewardship, as it is also an attempt to impose a direct obligation-derived from constitutional and international law-on the State to become a planetary climate steward.

\section{E. Conclusion}

Judging from the rise in climate cases worldwide, the increased visibility and impact of climate activist movements globally, and the strong emergence of "green" political parties in some parts of the world, the sense of urgency to act now to address climate change before it is too late has

\footnotetext{
${ }^{132}$ Neubauer, para. 202.

${ }^{133}$ Neubauer, para. 199.

${ }^{134}$ Aust, supra note 12.
} 
become tangible. There is a need to change human behaviour to protect planetary integrity, to avoid climate tipping points, and to remain within a safe planetary operating space. Law will and must continue to play an important part in changing human behaviour, because this is what law does best. Were a State's climate laws are insufficient to address climate change, both within that country and as part of the larger transnational climate law effort, we need astute judicial institutions to correct legislative anomalies within the permissible confines of the Rechtsstaat.

The German Constitutional Court made an important contribution to this endeavour in Neubauer. Its decision is historic for many reasons, and some of these will no doubt be further explored in detail elsewhere. I have focused in this article on the Court's highly innovative, and certainly contemporary, engagement with a planetary perspective that I believe has shaped the larger legal context within which it evaluated the constitutionality of Germany's climate laws. One might, but should not, logically assume that a court will embrace such a perspective when critically engaging with a complex global phenomenon such as climate change. After all, ideas such as tipping points, planetary boundaries, earth system law, earth system governance, planetary justice, and earth system vulnerability, have all only emerged relatively recently, and it will presumably still take time before they become more fully embedded within more formal legal and other social processes.

The emergence of these notions, however, does reflect the dawn of a new planetary consciousness that humanity, its regulatory institutions, and its legal actors including the courts, will have to embrace to be able to more effectively respond to earth system transformations that will only become more severe, unpredictable, and complex as we move deeper into the Anthropocene. The Constitutional Court made a singularly important pioneering contribution in this respect by showing what is possible when a court manages to revert to a planetary perspective in its adjudication of a domestic constitutional climate law dispute. We now have an example of how the judiciary can play a role in addressing climate law conflicts when and where they arise from within a planetary context as they inevitably do with climate change. Karlsruhe, in short, has not only strengthened German climate law, but has also set the stage for planetary climate litigation.

Cite this article: Kotzé LJ (2021). Neubauer et al. versus Germany: Planetary Climate Litigation for the Anthropocene?. German Law Journal 22, 1423-1444. https://doi.org/10.1017/glj.2021.87 